\title{
ECONOMIC EVALUATION OF DIFFERENT STRATEGY FOR WEED MANAGEMENT IN GARLIC PRODUCTION
}

\author{
Edita Štefanić \\ PhD, Full Professor, Faculty of Agrobiotechnical sciences Osijek, V. Preloga 1, 31000 Osijek, Croatia; \\ e-mail: estefanic@fazos.hr
}

Đorđe Maletić

Mag. Ing. Agr., OPG Đorđe Maletic, 32000 Vukovar, Croatia.

Dinko Zima

Dr. sc., College Professor, Polytechnic in Požega, Vukovarska 17, 34000 Požega, Croatia.

Ivan Štefanić

PhD, Full Professor, Faculty of Agrobiotechnical sciences Osijek, V. Preloga 1, 31000 Osijek, Croatia.

\begin{abstract}
A field experiment was conducted to evaluate various weed management options on garlic (Alium sativum L.) production in Northeastern Croatia. This study focus on how different strategies of weed control affects weed community composition and economic benefit of weed management. An experiment was arranged as a complete block design with three different weed management strategies: chemical control (PRE EM and POST EM), mechanical control (three times during the season), and combination of chemical and mechanical treatments, together with weeded checks. Data on weed density, fresh above weed biomass and garlic yield per $\mathrm{m}^{2}$ were collected at the end of the growing season, and were subjected to statistical and economic analysis. The mayor weeds found in the experimental plots were: Sorghum halepense, Ambrosia artemisiifolia, Cirsium arvense and Chenopodium album. The various weed growth (density and biomass) and yield varied with application of weed management practices. Significantly lower values of weed density and fresh above weed biomass were recorded on plots with mechanical and combination of chemical and mechanical treatments compared to weeded check. Chemical application gave in this study insufficient weed control and resulted in lower yields compared to the mechanical treatments and combination of mechanical and mechanical weed control. The best cost: benefit ratio was observed on treatment with combination of chemical and mechanical weed control and can be successfully applied to boost up the bulb yield in garlic and to harvest the maximum profit for farmers.
\end{abstract}

Key words: weed control efficacy, garlic, economic analysis 


\section{INTRODUCTION}

Garlic (Allium sativum L.) is an important bulbs crop worldwide, with a total production of 26.573.001 t (FAOSTAT database, 2016, http://www.fao.org/faostat/en/\#home). It is still under represented in the Croatian vegetable production, although there is significant demand for this crop. According to the TISUP 2017 (www.tisup.mps.hr), garlic was cultivated in Croatia on about 3.000 ha with the average yield of $3.000 \mathrm{~kg} / \mathrm{ha}$. However, the average yield of garlic is very low as compared to other leading countries due to many factors. One of the main limiting factors for garlic production is weed infestation, since weeds pose one of the most serious threats to this crop. Many researchers have reported garlic poor competition ability (Carlson and Kirby, 2005, Smith et al., 2008). Weeds compete with garlic for light, nutrients, water and space (Qasem, 1995). They are also host plants of several harmful insects and pathogens (Mishra et al., 2014, Zewde et al., 2007). Also, being a closely planted crop with very small canopy, non-branching habit, sparse foliage and shallow root system, garlic requires frequent irrigation and high fertilizer application that aid to variation in weed species and its abundance (Sahoo, et al., 2018). Moreover, according to Zimdahl (1980), garlic can tolerate weeds only up to three weeks after seedling, while Garcia et al. (1994) reported that economic threshold occurred from 61 to 74 days after transplanting during which time the crop must be kept weed free to maximize bulb yields. In Croatia, most of the farmers depend on manual labor for weeding garlic crop. This traditional method on small family farms include preparatory land tillage, hand weeding by hoe and hand pulling. The alternate method is the use of herbicides. However, weed management methods best suited for an individual grower should depend on several factors such as present weed species, crop variety and stage of growth of the crop, labor costs and availability (Bell and Boutwell, 2001.). Therefore, this study has been conducted to evaluate adequate weed management practice with the best agronomic yield and best economic benefit to the small and medium scale farmers.

\section{MATERIAL AND METHODS}

A field experiment was conducted at OPG (Family farm) Maletic situated in Brsadin village in Vukovar-Srijem county (Northeastern part of Croatia) during the 2018/19 growing season. This is an open and flat region with a warm and moderate to dry lowland climate (from the west to east part of the region, respectively) with an average yearly temperature $11.4^{\circ} \mathrm{C}$, and average yearly rainfall of $699 \mathrm{~mm}$ having the highest spring rainfall regime in June. The experiment was laid out in randomized block design with four replications and comprised of untreated control and three different weed management strategies: chemical control, mechanical control, and combination of chemical and mechanical treatments (Table 1).

All the plots have an area of $300 \mathrm{~m}^{2}$. Garlic cloves were planted on October $25^{\text {th }}, 2018$ at a rate of $2.800 \mathrm{~kg} / \mathrm{ha}^{-1}$ after seedbed preparation in first decade of October. The previous crop was sweet corn. Before the garlic was planted, the soil was thoroughly ploughed, leveled and fertilized with recommended doses of NPK (Parađiković, 2009). Row to row and plant to plant distances were kept $30 \mathrm{~cm}$ and $10 \mathrm{~cm}$ respectively. On plots with chemical treatments pendimethalin at a dose of 2,5 $\mathrm{l} / \mathrm{ha}^{-1}$ was sprayed 4 days after planting (DAP) and before the garlic emergence, while combination of clopyralid and fluroxypyr $\left(0,75+0,75 \mathrm{l} / \mathrm{ha}^{-1}\right)$ was applied post emergence in $180 \mathrm{DAP}$, when 
garlic has developed 3-4 leaves. Mechanical weed control included three hand weeding during the crop season (in early, mid and late of spring 2019). Combination of chemical and mechanical weed control included PRE-EM (pendimethalin) and POST-EM application (clopyralid and fluroxypyr) of herbicides on the same dose and time as on plots with chemical treatments and one mechanical weeding in the beginning of June 2019. No weeding was done in the weeded control plots. Garlic was harvested by hand on $7^{\text {th }}$ July 2019 using a small hand-hoe.

Table 1. Description of the experiment

\begin{tabular}{ccc}
\hline No. & Abbreviation & Treatment's description* \\
\hline 1 & UTC & Untreated control \\
2 & Chem & PRE-EM (4 DAP) and POST-EM (180 DAP) \\
3 & Mech & Three cultivations during the season \\
4 & Chem+Mech & PRE-EM (4 DAP) and POST-EM (180 DAP) + 1 cultivation \\
\hline & & Source: Author's research object
\end{tabular}

*PRE-EM: pre emergence application of herbicide; POST-EM: post emergence application of herbicide; DAP: days after planting

Data were collected at the end of the growing season (during the harvest) after the effect of herbicides and mechanical cultivation had become evident. Remaining weed community was sampled by means of four randomly placed $1 \times 1 \mathrm{~m}$ quadrates in each plot. Weeds were cut at ground level, separated by species, counted and weight. Bulb yield from these quadrats were also recorded (in $\mathrm{kg} / \mathrm{m}^{-2}$ ), and then converted to tons per ha for the economic analysis. Prior to statistical analyses the data were checked for normal distribution and homogeny of variance, and then were subjected to ANOVA using PROC GLM procedure in SAS (SAS v9.4, SAS Institute Inc., Cary, NC). The means were compared with Fisher's Protected LSD test at the $5 \%$ level of probability. To determine the most economically acceptable treatment, a partial budget analysis was performed to estimate the gross value of the garlic bulb yield from different weed management methods. The cost of production and gross margin of each treatment was calculated considering the current rate of agricultural operations right from preparatory tillage to harvesting including cleaning as well as market prices of inputs, seeds, fertilizers, insecticides and other variable costs.

\section{RESULTS AND DISCUSSION}

\subsection{Weed infestation}

The naturally occurring weed community found in the study area consisted of a mix of annual and perennial grasses and broadleaf weeds, common to this region (Štefanić et al., 2017). Weed community was dominated by a few species that had high relative abundance values and density (Table 2), while most of the species were of low abundance and density per square meter and with the low impact on the crop. 
Table 2. Dominant weed species throughout the experimental period

\begin{tabular}{|c|c|c|c|c|c|c|c|}
\hline \multirow[t]{2}{*}{ Species } & \multirow[t]{2}{*}{ Family } & \multicolumn{2}{|c|}{$\begin{array}{c}\text { Functional } \\
\text { groups* }\end{array}$} & \multicolumn{4}{|c|}{ Treatments } \\
\hline & & MF & LC & 1 & 2 & 3 & 4 \\
\hline Elytrigia repens (L.) Nevski & Poaceae & M & $P$ & - & - & + & - \\
\hline Ambrosia artemisiifolia L. & Asteraceae & $\mathrm{D}$ & $A$ & + & - & + & + \\
\hline Chenopodium album L. & Chenopodiaceae & $\mathrm{D}$ & $A$ & + & + & + & - \\
\hline Cirsium arvense L.Scop. & Asteraceae & $\mathrm{D}$ & $P$ & + & - & + & - \\
\hline Myosotis arvensis (L.) Hill. & Boraginaceae & $\mathrm{D}$ & $A$ & - & - & + & - \\
\hline Portulaca oleracea L. & Portulacaceae & $\mathrm{D}$ & $A$ & - & - & + & - \\
\hline Setaria viridis (L.) P. Beauv. & Poaceae & M & $A$ & - & - & + & - \\
\hline Sinapis arvensis $\mathrm{L}$. & Brassicaceae & $\mathrm{D}$ & $A$ & - & - & + & - \\
\hline Sorghum halepense (L.) Pers. & Poaceae & $M$ & $P$ & + & + & + & + \\
\hline
\end{tabular}

Source: Author's original work

The mayor weeds found in the experimental plots were: Sorghum halepense (Johnsongrass), Ambrosia artemisiifolia (common ragweed), Cirsium arvense (Canada thistle) and Chenopodium album (lambsquarters). Among them S. halepense and A. artemisiifolia are not only noxious weeds in the fields, but also a serious plant invaders in agricultural landscapes of the investigated region as well as in many parts of Europe (Chapman et al., 2017, Stefanic et al., 2017b). Dicot weeds were dominating more in the field than monocots, as well as annuals in relation to perennials. Weed control methods significantly affected the weed biomass and weed density (Table 3, Figure 1). Common ragweed (A. artemisiifolia) developed the significant aboveground biomass $\left(1,95 \mathrm{~kg} / \mathrm{m}^{2}\right)$ and had the highest density (26 plants) per $\mathrm{m}^{2}$ on untreated control plots, followed by C. arvense and C. album. Weed control efficiency ranged from $96 \%$ and $91 \%$ (chemical + mechanical and mechanical control respectively) to only $12 \%$ (chemical treatment). Mechanical and combination of chemical and mechanical treatments successfully controlled weeds, having only few shoots of dominant weeds per $\mathrm{m}^{2}$ with insignificant biomass. 
E. Štefanić, Đ. Maletić, D. Zima, I. Štefanić: Economic Evaluation of Different Strategy for Weed... Zbornik Veleučilišta u Rijeci, Vol. 8 (2020), No. 1, pp. $445-454$

Figure 1. Density and biomass of dominant weeds (per $\mathrm{m}^{2}$ ) in garlic experimental plot
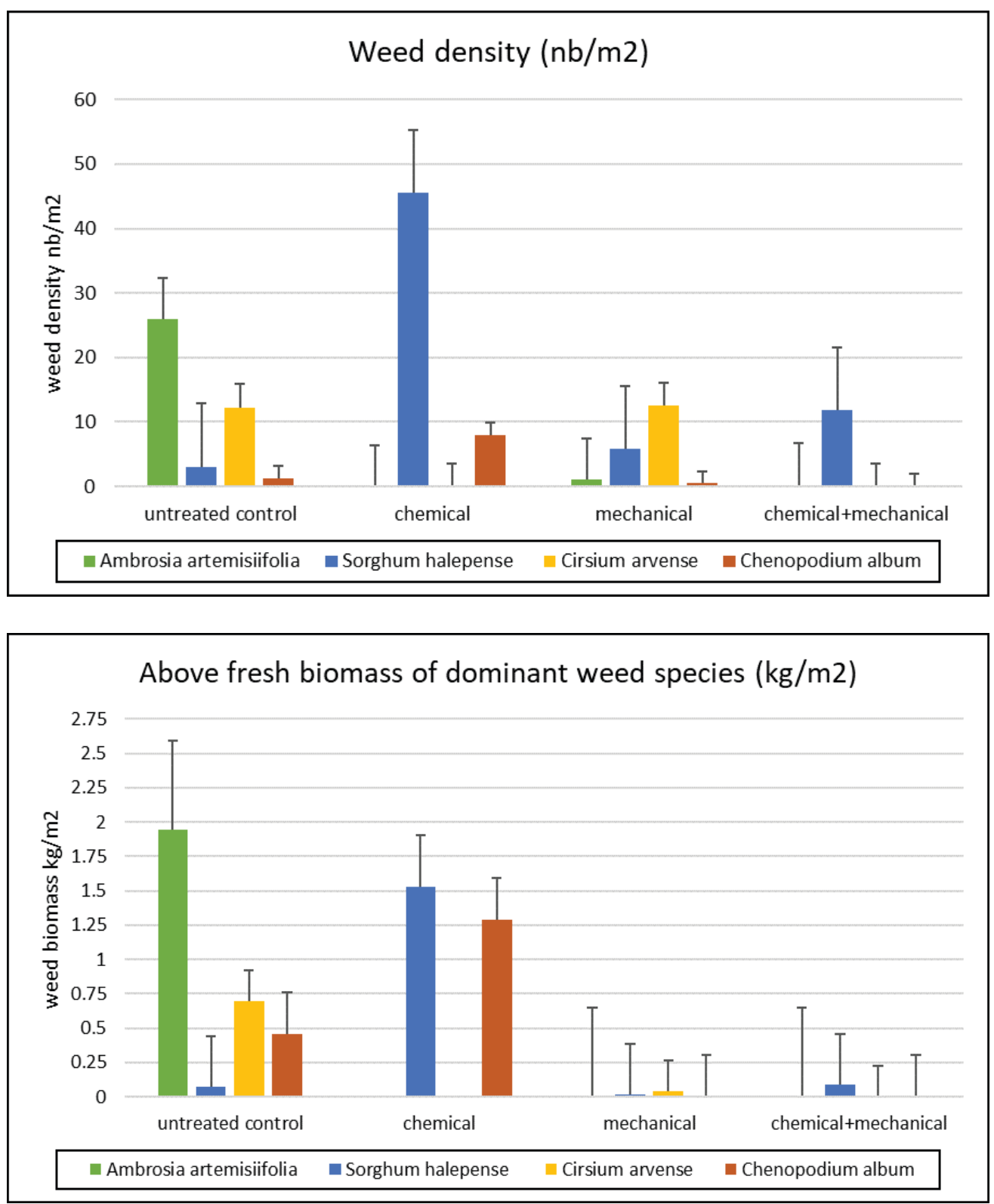

Source: Author's original work

Application of herbicides lead to insufficient control efficacy of two noxious weed species S. halepense and C. album, although in some other studies pendimethalin and clopyralid demonstrated a satisfactory control, particularly for Chenopodium album (Ujgur et al., 2010., Sahoo et al., 2018). These weeds developed at the end of growing season in average $1,53 \mathrm{~kg}$ and $1,29 \mathrm{~kg}$ of 
E. Štefanić, Đ. Maletić, D. Zima, I. Štefanić: Economic Evaluation of Different Strategy for Weed... Zbornik Veleučilišta u Rijeci, Vol. 8 (2020), No. 1, pp. 445-454

fresh above biomass per $1 \mathrm{~m}^{2}$ respectively. Regarding plant density per $\mathrm{m}^{2}$, S. halepense had 45 , and C. album 8 shoots in average.

Table 3. Analysis of variance (ANOVA) for the effect of weed management systems on weed density and biomass and garlic yield

\begin{tabular}{|c|c|c|c|c|c|c|}
\hline & & $\begin{array}{l}\text { Sum of } \\
\text { squares }\end{array}$ & df & Mean square & $F$ & Sig. \\
\hline \multirow{3}{*}{ 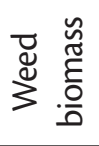 } & Between groups & 33,451 & 3 & 11,150 & 16,358 & 0,000 \\
\hline & Within groups & 8,180 & 12 & 0,682 & & \\
\hline & Total & 41,630 & 15 & & & \\
\hline \multirow{3}{*}{ 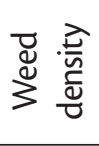 } & Between groups & 3738,500 & 3 & 1246,167 & 11,206 & 0,001 \\
\hline & Within groups & 1334,500 & 12 & 111,208 & & \\
\hline & Total & 5073,000 & 15 & & & \\
\hline \multirow{3}{*}{ 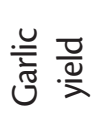 } & Between groups & 0,719 & 3 & 0,240 & 16,420 & 0,000 \\
\hline & Within groups & 0,175 & 12 & 0,015 & & \\
\hline & Total & 0,894 & 15 & & & \\
\hline
\end{tabular}

Results of this study are in agreement with experiment done by Vora and Mehta (1998) where herbicide application alone did not control weeds effectively but herbicide application followed by one hand hoeing gave the best results in garlic crop. Therefore, in minor crops like garlic, low availability of herbicides imposes to adopt an integrated use of non-chemical weed control method, or to combine those methods with existing herbicides option (Rahman et al., 2011). Also, the superiority of the mechanical and combination of chemical and mechanical weed control could be explained on the basis of better growth and higher uptake of nutrients under these practices which are corroborated with the findings Malik et al. (2017) and Vermani et al. (2001.). Mechanical control methods, however, over the last 20 years have become effective, fast and do not leave chemical residues on crops (Pannaci \& Tei, 2014).

\subsection{Garlic yield}

Weeds can reduce garlic yields considerably if not managed properly (Table 3, Fig. 2). This results, in which weeded check caused $82 \%$ reduction in the garlic yields when compared with chemical and mechanical treatment, show that weed control is very important for garlic production. However, in some other studies, due to unrestricted weed growth, yield loss in garlic was even up to $94.8 \%$ due to weed competition (Anon, 2009). The highest yield $(8,3 \mathrm{t} / \mathrm{ha}$ ) was obtained with combination of chemical and mechanical weed control. Mechanical weed control throughout the growing season gave the significantly lower yield (5,5 $\mathrm{t} / \mathrm{ha}$ ), while chemical application and weeded check had the worst results with $3,5 \mathrm{t} / \mathrm{ha}$ and $2,8 \mathrm{t} / \mathrm{ha}$, respectively. Also, these bulbs were of low quality and not for commercial sale. 
Figure 2. Garlic yield from different weed control treatments

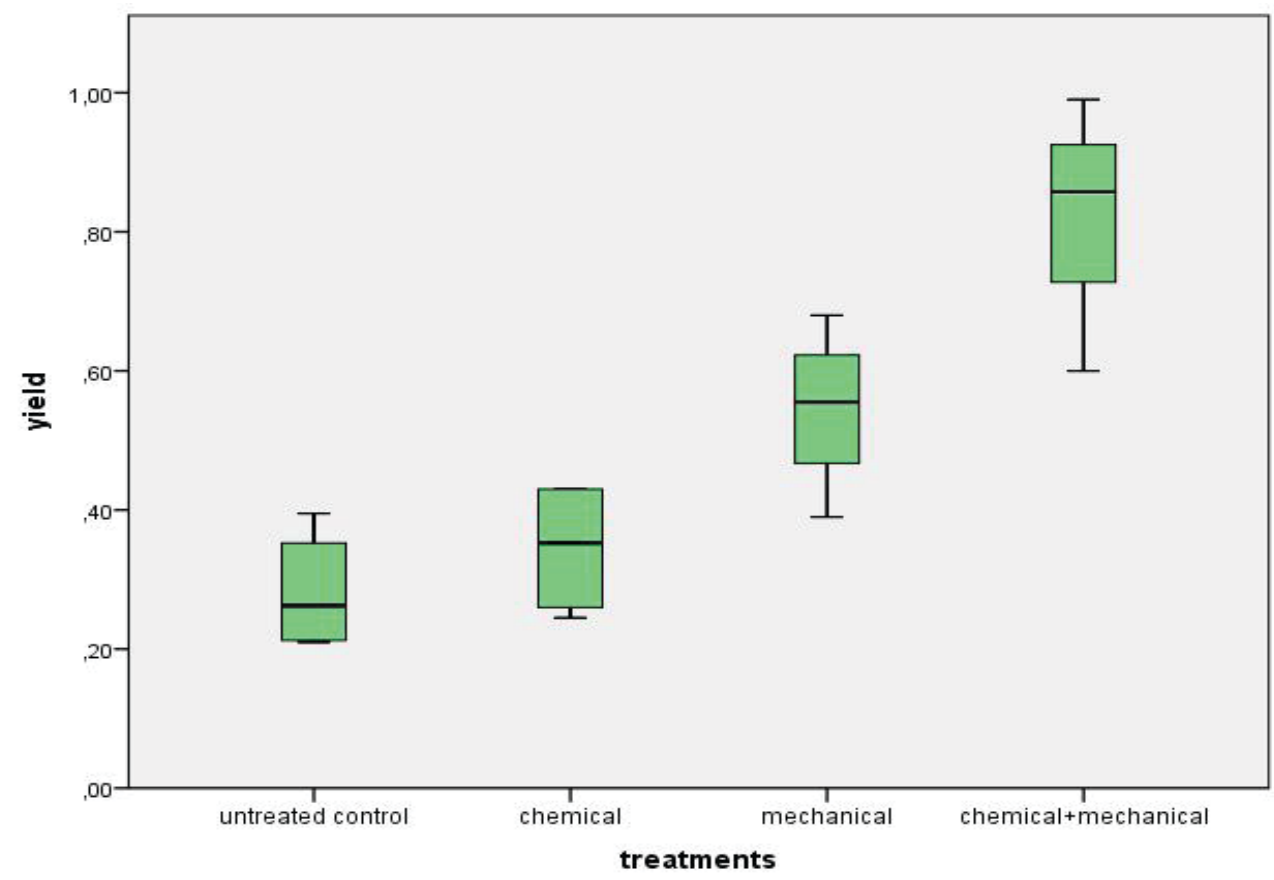

Source: Author's original work

\section{3 Economic analysis}

Weed management is an important factor that influences the economic importance of garlic production. Weeds not only compete for nutrients, water, light, space but also increase cost of labor and render the harvesting operations difficult. The impact of weed management method on expenditure, gross income, net income and benefit: cost ratio is shown in Table 4.

Table 4. Economic benefit of investigated weed management methods in garlic

\begin{tabular}{ccccc}
\hline Treatment & $\begin{array}{c}\text { Expenditure } \\
\left(\mathrm{kn} / \mathrm{ha}^{-1}\right)\end{array}$ & $\begin{array}{c}\text { Gross income } \\
\left(\mathrm{kn}^{-} \mathrm{ha}^{-1}\right)\end{array}$ & $\begin{array}{c}\text { Net income } \\
\left(\mathrm{kn} / \mathrm{ha}^{-1}\right)\end{array}$ & $\begin{array}{c}\text { Benefit cost ratio } \\
(\%)\end{array}$ \\
\hline UTC & 58,700 & 67.600 & 8.900 & 13,1 \\
Chem & 40.661 & 83.000 & 42.339 & 51 \\
Mech & 88.240 & 127.000 & 38.761 & 30,5 \\
Chem+Mech & 72.561 & 188.600 & 116.039 & 61,5 \\
\hline
\end{tabular}

Source: Author's original work

Based on a current market prices of herbicides, cultivations, and the wholesale price of garlic it could be concluded that combination of chemical and mechanical control method gave the best benefit cost ratio. Mechanical cultivation, due to the high labor costs, did obtained satisfactory economic benefit. Therefore, an integrated weed management approach (IWM) could be a good 


\section{E. Štefanić, Đ. Maletić, D. Zima, I. Štefanić: Economic Evaluation of Different Strategy for Weed...}

Zbornik Veleučilišta u Rijeci, Vol. 8 (2020), No. 1, pp. $445-454$

option for a successful garlic production. IWM provides diverse weed control tools that are feasible in a given socio-economic situation (Mehmood et al., 2006, Lamichhane et al., 2017).

\section{CONCLUSION}

In present study, weed community in garlic dominated with johnsongrass (Sorghum halepense), common ragweed (Ambrosia artemisiifolia) Canada thistle (Cirsium arvense) and lambsquarters (Chenopodium album). Those weeds compete with garlic for nutrients, soil moisture, space, and light and considerably reduce the yield, quality and value of the crop through increased production and harvesting costs. Chemical treatment alone did not provide a season long weed control. Manual weeding is a very expensive laborious method of weed control, even often damages the crop. This research demonstrated that good option (higher yield and economic benefit) could be implementation of IWM i.e. combination chemical and mechanical weed control. This treatment successfully controlled weeds, gave the highest yield and the best economic benefit.

\section{REFERENCES}

Anonymous. (2009) Crop-weed competition studies in onion and garlic. Annual Report 2008-09. Directorate of Onion and Garlic, Indian Council of Agricultural Research, Rajgurunagar, Dist. Pune, Maharashtra, 2009, 21-22

Bell, C.E., Boutwell, B.E. (2001) Combining Bensulide and Pendimethalin Controls Weeds in Onions. California Agriculture, January-February, pp. 35-38.

Carlson, H.L., Kirby, D. (2005) Effect of Herbicide Rate and Application Timing on Weed Control in Dehydrator Onions. University of Florida, Intermountain Research and Extension Center, Number, 115: p. 4.

Chapman, D.S., Scalone, R., Stefanic, E., Bullock, J.M. (2017) Mechanistic species distribution modeling reveals a niche shift during invasion. Ecology 98, 1671-1680.

Garcia, D. C., Barni, V., Storck, L. (1994) Influence of the weed competition on yield of onion bulbs. Pesquisa Agropecuaria Brasileira, 29, No.10., 1557-1563.

Lamichhane, J.R., Devos, Y., Beckie, H.J., Owen, M.D., Tillie, P., Messean, A., Kudsk, P. (2017) Integrated weed management systems with herbicide-tolerant crops in the European Union: Lessons learnt from home and abroad. Critical Reviews in Biotechnology, 37, No. 4, 459-475.

Malik, S., Sharangi, A.B., Datta, N. (2017) Herbicidal Options in Managing Weeds towards Growth and Yield Dynamics of Single Clove Garlic. International Journal of Agriculture Sciences 9., No. 1, 3627-3630.

Mishra, R.K., Jaiswal, R. K., Kumar, D., Saabale, P.R., Singh, A. (2014) Management of major diseases and insect pests of onion and garlic: A comprehensive review, Journal of Plant Breeding and Crop Science 6 (11), 160-170.

Mehmood, T., Khokhar, K.M., Shakeel, M. (2006) Integrated weed management practices in garlic crop in Pakistan. Crop Protection 26, 1031-1035.

Parađiković, N. (2009) Opće i specijalno povrćarstvo. Sveučilište J.J. Strossmayera u Osijeku, Poljoprivredni fakultet Osijek, pp. 536.

Qasem, J.R. (1995): Weed competition in garlic (Allium sativum L.). Journal of Horticultural Science 71, 41-48. Pannaci, E., Tei, F. (2014) Effect of mechanical and chemical methods on weed control, weed seed rain, and crop yield in maize, sunflower and soybean. Crop Protection 64, 51-59.

Rahman, H., Ullah, K., Sadiq, M., Khan, H.U., Khan, M.A., Khattek, A.M. (2011) Relationship between manual weeds removal timings and garlic *Allium sativum L.) production. Pak.J.Weed.Sci.Res. 17 (3), 285-292. 
Sahoo, S., Oatel, T.U., Baldanya, M.J., Chawan, A., Murmu, S. (2018) Effect of herbicide on crop growth and yield of garlic (Allium sativum L.). International Journal of Chemical Studies 6, No. 3., 3248-3250.

Smith, R., Fennimore, S.A., Orloff, S., Poole, G.J. (2008) In: Bell, C.E., Cudney, D.W., Fennimore, S.A., Orloff, S.:Weeds. UC IPM Pest Management Guidelines: Onion and Garlic. University of California, Agriculture and Natural Resources, Publication, p. 3453.

Štefanić, E., Kovačević, V., Dimić, D., Štefanić, l., Antunović, S. (2017a) Changes in weed species composition in northeastern Croatian row crops from 1977 to 2015. Herbologia, Vol. 16, No. 2, 57-62.

Štefanić, E., Dimic, D., Sudarić, A., Štefanić, I.,Antunović, S., Horvat, G. (2017b) Seasonal dynamic of weed biomass in narrow and wide row soybean (Glycine max (L.) Merr.). . Herbologia, Vol. 16, No. 2. 57-62.

Uygur, S., Gürbüz, R., Uygur, N. (2010) Weeds of onion fields and effects of some herbicides on weeds in Cukurova region, Turkey. African Journal of Biotechnology Vol. 9(42), 7037-7042.

Vermani , A., Nandal, T.R., Singh, R. (2001) Nutrient uptake and economic weed management in garlic (Allium sativum L.). Indian Journal of Weed Science.33. No. 3\&4, 225- 226.

Vora, V.D., Mehta, D.R. (1998) Integrated wed management in winter garlic. Agric. Sci. Digest Karnal 18 (4), 237-239.

Zewde, T., Fininsa, C., Sakhuja, P.K., Ahmed, S. (2007) Association of white rot (Sclerotioum cepivorum) of garlic with environmental factors and cultural practices in the North Shewa highlands of Ethiopia. Crop Protection 26, 15661573.

Zimdahl, R. (1980) Weed-crop competition: A review. International Plant Protection Center. Oregon State University, Corvallis, Oregon, pp: 195. 


\title{
EKONOMSKA EVALUACIJA RAZLICITIH STRATEGIJA SUZBIJANJA KOROVA U PROIZVODNJI CESNJAKA
}

\author{
Edita Štefanić
}

Dr. sc., redoviti profesor, Fakultet agrobiotehničkih znanosti Osijek, V. Preloga 1, 31000 Osijek, Hrvatska; e-mail:estefanic@fazos.hr

Đorđe Maletić

Mag. ing. agr., OPG Đorđe Maletic, 32000 Vukovar, Hrvatska.

\section{Dinko Zima}

Dr. sc., profesor visoke škole, Veleučilište u Požegi, Vukovarska 17, 34000 Požega, Hrvatska.

\section{Ivan Štefanić}

Dr. sc., redoviti profesor, Fakultet agrobiotehničkih znanosti Osijek, V. Preloga 1, 31000 Osijek, Hrvatska.

\section{SAŽETAK}

Poljski pokus je proveden na području sjeveroistočne Hrvatske s ciljem evaluacije različitih strategija suzbijanja korova u češnjaku (Alium sativum L.). Predmet ovog istraživanja bio je utvrditi kako različite strategije suzbijanja korova utječu na korovnu zajednicu u češnjaku i kakav je ekonomski učinak svakog od istraživanih tretmana. Pokus je postavljen po slučajnom blok rasporedu sa tri različita tretmana suzbijanja korova: kemijsko (sa PRE-EM i POST-EM primjenom), mehaničko (tri puta tijekom vegetacijske sezone) i kombinaciju kemijskog i mehaničkog suzbijanja. Zakorovljena, kontrolna varijanta je također bila uključena u pokus. Dobiveni podatci o gustoći korova, svježoj nadzemnoj biomasi korova i prinosu češnjaka prikupljeni su na kraju vegetacijske sezone te statistički i ekonomski analizirani. Najznačajniji korovi tijekom provedbe pokusa bili su: Sorghum halepense, Ambrosia artemisiifolia, Cirsium arvense and Chenopodium album. Primjenjene strategije suzbijanja korova različito su utjecale na gustoću i nadzemnu biomasu korova te na prinos češnjaka. Signifikantno manja gustoća korova i njihova nadzemna biomasa u usporedbi sa zakorovjenom kontrolom utvrđena je na parcelama s mehaničkim suzbijanjem korova i s kombinacijom mehaničkog i kemijskog suzbiljanja. Aplikacija herbicida u ovom pokusu nije se pokazala uspješnom i ostvarila je na kraju vegetacijske sezone signifikantno niži prinos u odnosu na ostale tretmane. Tretman s najboljem omjerom troškova i koristi jest kombinacija kemijskog i mehaničkog suzbijanja korova i može se preporučiti farmerima kao uspješna strategija za postizanje visokog pronosa i ostvarenja maksimalnog profita. 